\title{
KLASZTER-ANALÍZIS A BAROMFIHÚS-TERMÉKEK PIACÁN
}

\author{
Dr. Vincze-Lendvai Edina $\mathrm{PhD}$ \\ fỏiskolai docens \\ Szegedi Tudományegyetem Mérnöki Kar
}

SUMMARY

The products of the poultry species play a more important role in the supply with food of the population of Eurth. In our research we made a representative 1000-persons- questionnaire factfinding. We wanted to take the measure of consumers' attitudes about processed poultry products. After the apprehension of the answers we made factor- and cluster-analysis. The 97,6 percents of the poultry-products consumers was divided into 7 factors and 4 clusters respectively by the factor- and cluster-analysis based on the life-style, the demography and the attitudes. The most substantial factor is the price for the members of the " $A$ " cluster, and the quality for the people of the " $B$ ". Persons belong to " $\mathrm{C}$ " cluster like the branded, convenience products, and the moneyless pensioners from " $\mathrm{D}$ " think the most important factor is the price.

\section{Bevezetés}

A világ baromfitartásában évek óta óriási mértékü fellendülés tapasztalható, a baromfifajok termékei egyre fontosabb szerepet töltenek be a Föld lakóinak élelmezésében. A fehérjében gazdag, zsírban szegény számyasokból egyre többet eszünk, az összes húsfogyasztáshoz viszonyítva kétévenként 1\%-kal többet.

Magyarországon a 60-as években kezdődött el a hagyományos baromfitenyésztés fejlesztése, a nemzetközi együttmüködésbe való bekapcsolódás. A korszerű vágó-feldolgozó technológia átvételével a magyar baromfiipar meghatározó tényezỏvé vált mind a hazai, mind a nemzetközi piacokon (http://www.jomagyarbaromfi.hu).

A baromfifogyasztás elöretörése a kilencvenes évek közepén kezdödött Magyarországon, amelynek oka nemcsak a sertéshús árnövekedésében keresendő, hanem a fogyasztóközönség táplálkozási szokásainak átalakulásában is. Az elérhetöbb ár mellett a baromfihúsról köztudott, hogy egészséges, könnyen emészthetö húsféleség (TÓTH, 2002).

A kereskedelemben a feldolgozott termékek gazdag választéka található, melyekkel a gyártó a vásárlói igények sokszínüségéhez is igyekezett igazodni. Megtalálható közöttük a 
friss, azonnal fogyasztható, a rövidebb vagy hosszabb ideig tárolható, a különösebb kezelést, hütést nem igénylő és az igen egyszerü konyhatechnikai müvelettel - sütés, fözés, melegítés -pár perc alatt a tányérra varázsolható termék is.

\section{Anyag és módszer}

Munkánk során a baromfihúsból készült termékekkel kapcsolatos fogyasztási és vásárlási szokások megismerése - 1000 fös kérdöíves reprezentativ felmérés - volt a cél.

Az alapsokaságból vett minta összeállításának alapja a Központi Statisztikai Hivatal 2001 -es népszámlálási adatai voltak. A kiválasztás a BERKE (2003) által kidolgozott többlépcsös mintavételi eljárás továbbfejlesztésével történt.

A megbizható eredmények alapja - a reprezentativitás mellett - a mintavétel módja. Ehhez az úgynevezett „véletlen séta” (random walking) módszerét alkalmaztuk. A kérdezöbiztosok a kiválasztott nagyobb településeken a HOFFMANN et al. (2001) által is javasolt szisztéma szerint keresték fel a vảlaszadókat: egy meghatározott helyröl kiindulva, minden második ház első emeleti lakójához csöngettek be. Falvakban ez az eljárás természetesen nem volt megvalósitható, segitöim ott minden második házat keresték fel.

Az adargyưjtés során a ,face-to-face” módszert alkalmaztuk, melynek során a kérdezöbiztos az illető szernély lakásán (in hall) töltette ki a kérdőivet. A munkát kiképzett kérdezöbiztosok végezték el, akiket szúrópróbaszerüen ellenöriztünk.

Az alkalmazott kérdöiv - a könnyebb feldolgozhatóság érdekében - döntően zárt kérdéseket tartalmaz, melyek túlnyomó részénél intervallumskála segítségével válaszolhattak a megkérdezettek. A skálák legtöbbször ötfokozatúak, hiszen az iskolai osztályzatoknak megfelelően ezt tudják a válaszadók legjobban értelmezni, illetve használni. Néhány esetben hetes skálát alkalmaztunk, pl. amikor a fogyasztási gyakoriságot vizsgáltuk, az 5 fokozat nem lett volna elegendö. A zárt kérdések mellett, bizonyos esetekben, nyitott kérdéseket tettünk fel. A kérdöív az alábbi 5 területet érintette:

1. A baromfihúsból készült továbbfeldolgozott termékek fogyasztási szokásai;

2. Ezen gyártmányokkal kapcsolatos vásárlási szokások;

3. Image-vizsgálat;

4. Háttérváltozók;

5. Életstílus-elemzés.

$\mathrm{Az}$ életstilus-elemzéssel a megkérdezetteket fogyasztás-lélektani jellemzőik alapján sorolhatjuk különböző osztályokba. A faktor analizis elvégzéséhez a kérdőiv legvégén található, életmódra vonatkozó állitásokat vettük figyelembe. Az eljárással faktorokat: „olyan 
elméleti változók, amelyek a valós változókkal szoros korrelációs kapcsolatban vannak, egymástól csaknem függetlenek és számuk a vizsgált mintákhoz képest minimális" és hozzájuk tartozó faktorsúlyokat: a faktorok konkrét vảltozókkal való kapcsolatát kifejező számérték (FALUS-OLLÉ, 2000) kaptunk.

\section{Eredmények és értékelésük}

Az alkalmazott 21 változó alapjản - a varimax rotációt követöen - 7, egymástól igen jól elkülönülő faktort alakítottunk ki. A Kaiser - Meyer - Olkin mutató (KMO) értéke meghaladja a 0,5-ös értéket - 0,743 - így a változószett alkalmas a faktor-analízisre. A Bartlett tesztszignifikanciája pedig $0,000 \mathrm{lett,} \mathrm{eszerint} \mathrm{a} \mathrm{változók} \mathrm{páronként} \mathrm{nem} \mathrm{függetlenek}$ (SZÉKELY -BARNA, 2003). A kapott faktorokat és faktorsúlyokat az 1. tảblázat mutatja be (az $1000 \mathrm{db}$ kérdōívböl csak 985 esetében töltötték ki értékelhető módon az életstíluselemzést).

\section{1. táblázat: Rotált faktor mátrix $(\mathrm{n}=985)$}

\begin{tabular}{|c|c|c|c|c|c|c|c|}
\hline \multirow{2}{*}{ változó } & \multicolumn{7}{|c|}{ faktorsuilyok } \\
\hline & 1.faktor & 2.faktor & 3. faktor & 4. faktor & 5.faktor & 6. faktor & 7. faktor \\
\hline fontos a környezet & $-0,006$ & 0,081 & 0,160 & 0,625 & $-0,068$ & 0,014 & 0,290 \\
\hline fontos, mir gondolnak róla & 0,052 & 0,022 & 0,009 & $-0,046$ & 0,247 & $-0,078$ & 0,746 \\
\hline hisz a családi értékben & $-0,019$ & 0,052 & 0,117 & 0,222 & $-0,135$ & 0,212 & 0,676 \\
\hline márkás terméket vesz & 0,171 & 0,646 & $-0,084$ & 0,007 & 0,324 & 0,039 & 0,162 \\
\hline odafigyel az árra & 0,024 & $-0,096$ & 0,725 & 0,010 & $-0,034$ & 0,019 & 0,042 \\
\hline hisz a reklámnak & 0,023 & $-0,013$ & $-0,051$ & $-0,003$ & 0,782 & $-0,035$ & 0,114 \\
\hline figyel az étkezésére & 0,097 & 0,170 & $-0,021$ & 0,340 & 0,136 & 0,524 & 0,103 \\
\hline elsóként próbál ki újat & 0,197 & 0,363 & 0,006 & $-0,023$ & 0,627 & 0,138 & $-0,051$ \\
\hline szeret ot thon fôzni & $-0,085$ & 0,017 & 0,252 & 0,013 & 0,013 & 0,730 & $-0,010$ \\
\hline dohányzik & 0,425 & $-0,033$ & 0,103 & $-0,499$ & $-0,213$ & $-0,129$ & 0,068 \\
\hline sport $=$ fittség & 0,287 & 0,164 & $-0,062$ & 0,624 & $-0,072$ & 0,029 & $-0,010$ \\
\hline jobb minöségért többet fizet & 0,196 & 0,703 & $-0,246$ & 0,205 & 0,031 & 0,059 & 0,141 \\
\hline szeret otthon lenni & $-0,488$ & 0,238 & 0,365 & $-0,079$ & $-0,184$ & 0,181 & 0,179 \\
\hline vezetõ a baráti körében & 0,636 & 0,221 & $-0,031$ & $-0,154$ & 0,010 & $-0,130$ & 0,015 \\
\hline megtervezi a vásárlásait & 0,104 & 0,042 & 0,573 & $-0,130$ & 0,033 & 0,313 & 0,106 \\
\hline szereti a változatos életet & 0,688 & 0,120 & $-0,011$ & 0,227 & 0,058 & $-0,008$ & 0,040 \\
\hline optimista & 0,547 & $-0,005$ & $-0,025$ & 0,164 & 0,162 & 0,275 & 0,038 \\
\hline sportol & 0,377 & 0,138 & $-0,192$ & 0,452 & 0,149 & 0,024 & $-0,322$ \\
\hline áremelésnél is márkásat vesz & $-0,050$ & 0,726 & 0,148 & 0,148 & $-0,012$ & 0,000 & $-0,148$ \\
\hline aggódó & $-0,230$ & $-0,025$ & 0,672 & 0,072 & 0,011 & $-0,075$ & 0,002 \\
\hline kényelmes terméket szeret & 0,075 & 0,099 & 0,261 & 0,123 & 0,442 & $-0,529$ & $-0,052$ \\
\hline
\end{tabular}

Az együtthatók nagy része 0,5 feletti lett, így a szegmentáláshoz elegendö lett volna a faktoranalizissel foglalkozni (KOMÁROMI, 1997), a pontosítás, és a kevesebb szegmens kialakítása érdekében azonban a klaszter-analizist (K-Means Cluster) is elvégeztük. Ezzel a módszerrel 4 fogyasztói klaszterhez jutottunk (2. táblázat). A 4 klaszterba összesen 976 
fogyasztót tudtunk besorolni, öket - az egyszerüség kedveért - $100 \%$-nak vettük, így a továbbiakban eltekintünk azoktól, akik egyik klaszterbe sem illeszthetők bele. Eszerint az „A” klaszterbe a kérdőiv-kitöltők 16,7 \%-a, a „B"-be a 36,6\%-a, a „C"-be a 23,2\%-a, s a „D”-be a $23,5 \%$-a került.

\section{2. táblázat: A klaszter-analízis eredménye}

\begin{tabular}{|c|c|c|}
\hline Klaszter & \multicolumn{2}{|c|}{$\begin{array}{c}\text { Az egyes klaszterekbe tartozók } \\
\text { száma }\end{array}$} \\
\hline & $f o ́$ & $\%$ \\
\hline $\mathrm{A}$ & 163 & 16,7 \\
\hline $\mathrm{B}$ & 358 & 36,6 \\
\hline $\mathrm{C}$ & 226 & 23,2 \\
\hline $\mathrm{D}$ & 229 & 23,5 \\
\hline Összesen & 976 & 100,0 \\
\hline Kimaradt & 24 & - \\
\hline
\end{tabular}

A klaszterek összetételét - a háttérváltozók alapjản - kereszttáblák segítségével ismertük meg. A föbb megállapitásokat a 3. táblázat tartalmazza.

\section{3. táblázat: A klaszterek összetétele - a háttérváltozók alapján}

\begin{tabular}{|c|c|c|c|c|}
\hline Jellemzök & $A$ & $B$ & $C$ & $D$ \\
\hline $\begin{array}{c}\text { nem } \\
\mathrm{p}=0,000\end{array}$ & vegyes & nö & férfi & vegyes \\
\hline $\begin{array}{c}\text { családi állapot } \\
\mathrm{p}=0,000\end{array}$ & elvált & házas & $\begin{array}{c}\text { nótlen } / \\
\text { hajadon }\end{array}$ & özvegy \\
\hline $\begin{array}{c}\text { kor } \\
\mathrm{p}=0,000\end{array}$ & $40-59$ év & $30-39$ év & $16-29$ év & 60 év felett \\
\hline $\begin{array}{c}\text { iskolai végzettség } \\
\mathrm{p}=0,000\end{array}$ & szakmunkás & középfokú & felsófokú & $\begin{array}{c}\text { max. } 8 \\
\text { általános }\end{array}$ \\
\hline $\begin{array}{c}\text { jövedelem-érzet } \\
\mathrm{p}=0,005\end{array}$ & átlag alatti & átlagos & $\begin{array}{c}\text { jelentösen } \\
\text { az átlag } \\
\text { felett }\end{array}$ & átlag alatti \\
\hline
\end{tabular}

Az A-D csoportok fontosabb jellemzöit egyrészt az életstílus-elemzés, másrészt a fogyasztással és vásárlással kapcsolatos válaszok segítségével irhatjuk le. Ehhez elöször is kiszámoltuk az állitások átlagait az egyes klaszterek tükrében (4. táblázat), majd elemeztük a baromfiipari termékekkel kapcsolatos magatartásukat, attitüdjeiket. 


\section{4. táblázat Az egyes klaszterek jellemzỏi az életstilus alapján}

\begin{tabular}{|c|c|c|c|c|}
\hline & $A$ klaszter & B klaszter & C klaszter & D klaszter \\
\hline & \multicolumn{4}{|c|}{ átlagok } \\
\hline fontos a környezet & 4,626 & 4,877 & 4,416 & $4, \overline{550}$ \\
\hline fontos, mit gondolnak róla & 3,135 & 3,335 & 2,903 & 2,707 \\
\hline hisz a családi értékben & 4,104 & 4,352 & 3,619 & 3,786 \\
\hline márkás terméket vesz & 2,546 & 3,316 & 3,168 & 2,166 \\
\hline odafigyel az árra & 4,294 & 4,101 & 3,288 & 3,869 \\
\hline hisz a rekiámnak & 1,601 & 2,053 & 2,177 & 1,729 \\
\hline figyel az étkezésére & 3,221 & 3,799 & 3,327 & 2,996 \\
\hline elsóként próbál ki újat & 1,687 & 2,302 & 2,288 & 1,445 \\
\hline szeret otthon fôzni & 3,896 & 4,109 & 2.310 & 3,039 \\
\hline dohányzik & 4,669 & 1,098 & 2,823 & 1,131 \\
\hline sport $=$ fittség & 3,859 & 4,486 & 4,363 & 3,624 \\
\hline jobb minóségért többet fizet & 2,939 & $3, \overline{980}$ & 3,801 & 2,603 \\
\hline szeret otthon !enni & 3,994 & 3,788 & 2,425 & 3,969 \\
\hline vezetó a baráti körében & 2,319 & 2,503 & 3,040 & $1,79 \overline{9}$ \\
\hline megtervezi a vásárlásait & 3,417 & 3,411 & 2,212 & 2,590 \\
\hline szereti a változatos életet & 3,429 & 3,824 & 4,150 & 2,624 \\
\hline optimista & 2,847 & 3,408 & $\mathbf{3 , 5 8 4}$ & 2,459 \\
\hline sportol & 1,736 & $2,45 \overline{5}$ & 3,252 & 1,603 \\
\hline áremelésnél is márkásat vesz & 2,699 & 3,391 & 3,013 & 2.520 \\
\hline aggódó & 3,656 & 3,464 & 2,425 & 3,528 \\
\hline kényelmes terméket szeret & 2,663 & 2,830 & 3,018 & 2,611 \\
\hline
\end{tabular}

Az A klaszterbe férfiak-nők vegyesen tartoznak, 40-59 év közöttiek, fölcg elváltak, alacsony iskolai végzettségüek, akik átlag alatti jövedelemmel rendelkcznek. Ebböl adódóan fontos számukra az ár, minden vásárlást gondosan megterveznek, aggódnak a jövőjük miatt, nem szívesen mozdulnak ki otthonról (egyetlen szórakozásuk a dohányzás). A baromfitermékeket föleg azért fogyasztják, mert „olcsónak" tartják. A párizsi és a virsli náluk kerül legtöbbször az asztalra. A termék-kiválasztásnál az ár, az elérhetőség és a megszokás játszik fontos szerepet, vásárláskor a diszkontokat keresik fel legtöbbször. Az árakat a „,drága” és a „még elviselhetō" között érzékelik, a minőséggel a legkevésbé vannak megelégedve.

A B klaszter tagjai 30-39 év közötti, középfokú végzettségü, férjezett nök, akik átlagos gazdasági körülmények között élnek. Ennek megfelelöen már nemcsak az ár, hanem a minőség is érdekli őket, bár, ők is elöre eltervezik, hogy.mit vásárolnak. Odafigyelnek az étkezési szokásaikra, szeretnek otthon fözni, fontos számukra a család és mások véleményével is törödnek. Nem mozognak rendszeresen, de elismerik, hogy a sport a fittség záloga. A baromfi-készítményeket egészségesnek gondolják, és jobban szeretik a többi húsfajtánál. Ök fogyasztanak a legritkábban panírozott termékeket. Döntéseiket az íz, a termék ismertsége, az 
állandó minőség, a márka, a gyártó cég, a külsỏ megjelenés, valamint a higiéniai szempontok motiválják. A baromfi-készítmény-vásárlók legnagyobb \%-a ebböl a csoportból kerül ki. A hiper- és a szupermarketeket kedvelik. Az árakat elfogadhatónak tartják, a minöséggel ők vannak a legjobban megelégedve.

A C klaszter ezzel szemben fiatal, egyedülállo, felsőfokú végzettségü, magas fizetéssel rendelkezö férfiakból áll. Ök azok, akik márkás, kényelni termékeket vesznek,.. szeretnek eljárni szórakozni, nem szeretnek fözni, a szabadidejükben sportolnak, a baráti körükben a vezetők közé tartoznak, optimista életszemléletủek. A több csoport tagjaihoz képest hisznek a reklámoknak, és elsők között próbálják ki az új termékeket. A baromfihúsból gyártott készitményeket elsősorban azért választják, mert jobban szeretik a többinél. Ők fogyasztják a leggyakrabban a felvágottakat, a sonkákat, a májasokat, a pácolt-fưstölt-fött termékeket és a gyorsfagyasztott termékeket. Számukra a gyártmány reklámozottsága és a csomagolás az elsödieges. Ök azok, akik a legkevésbé vásárolnak baromfi-termékeket, akik mégis, azok a hipermarketekbe mennek elsősorban. Az árak szerintük a leginkább „reálisak”, a minőséggel meg vannak elégedve. A többiekhez képest kiugróan magas azok aránya, akik impulzusszerüen vásárolnak.

A D klaszterbe a 60 év feletti, megözvegyült, alacsony iskolai végzettségü, kisnyugdijjal rendelkezö férfiakat és nöket sorolhatjuk. Ök egyáltalán nem vesznek márkás termékeket, nem törödnek az étkezési szokásaikkal, nem szeretik a késztermékeket (hiszen drágák), nem foglalkoznak az újdonságokkal. Nem fontos számukra, hogy változatos legyen az életük, a legkevésbé optimisták, nem törődnek mások véleményével, se nem sportolnak, se nem dohányoznak. (A jellemzésüknél nem a legmagasabb, hanem a legalacsonyabb átlagértékkel rendelkező állításokat kellett figyelembe venni.) A baromfi-gyártmányokat alacsony áruk miatt kedvelik. Elsősorban az ár alapján választanak, a legkevésbé őket érdekli az állandó minőség, a külső megjelenés, illetve a higiénia. Kisebb élelmiszerboltokban és üzletláncokban vásárolnak. Az árakról ugyanaz a véleményük, mint az $\mathrm{A}$ klaszter tagjainak, a minőséget kicsit jobbnak találják.

\section{4. Összefoglalás}

Ezerfős reprezentatív felmérést végeztünk a baromfiipari termékek fogyasztási és vásárlási szokásaival kapcsolatosan. Az adatok feldolgozása során klaszter-analízist is készítettünk, így 7 faktorhoz, valamint 4 klaszterhez jutottunk, ahová a megkérdezettek 97,6\%-át tudtuk elhelyezni. Jellemeztük a klasztereket, az oda soroltak életstílusa, illetve a demográfiai 
háttérváltozók és a baromfiipari termékekkel kapcsolatos viselkedésük alapján. Az A klaszter tagjai számára az ár a lényeges szempont, míg a $\mathrm{B}$ klasztert alkotó válaszadók a minőséget keresik. A C klaszterbe tartozók a márkás, kényelmi termékeket kedvelik, a D klaszter kispénzü, idős nyugdíjasai szintén az árat tartják a legtontosabbnak.

\section{Irodalomjegyzék}

1. Berke Sz 2003: A funkcionális minőség összetevőinek fogyasztói megítélèse állati eredetü alapélelmiszereknél. PhD értekezés. Kaposvár

2. Falus I. - Ollé J 2000: Statisztikai módszerek pedagógusok számára. Okker Kiadó Kft. Budapest

3. Hoffmann M. - Kozák Á. - Veres Z 2001: Piackutatás. Müszaki Könyvkiadó. Budapest

4. Komáromi N. 1997: A magyar élelmiszerfogyasztók szegmentációja. Marketing \& Menedzsment 31 (6) 71-73

5. Székely M.- Barna I. 2003: Túlélökészlet az SPSS-hez. Typotex Kiadó. Budapest

6. Tóth E 2002: Mi van a kosárban? A baromfi 5 (2) 78-79

7. http://www.jomagyarbaromfi.hu/inner.php?page=emb_baromfifajtak\&menu=emb 